(C) K. Kairemo, T. Joensuu, 2018

UDC 616.65-006.6-08:539.16

DOI 10.21886/2308-6424-2018-6-1-65-75

ISSN 2308-6424

\title{
Lu-177-PSMA treatment for metastatic prostate cancer - case examples of miracle responses
}

\author{
K. Kairemo, T. Joensuu \\ Docrates Cancer Center; Helsinki, Finland
}

\begin{abstract}
Prostate specific membrane antigen (PSMA) is expressed in unfavorable prostate cancer. PSMA is basis for new diagnostics and theranostics. 177Lu-PSMA radioligand therapy is mainly used for patients with endstage prostate cancer. This report describes two patients: one patient with a multiple recurrences and one with extensive metastastic disease during the first visit. Both these patients were treated with 177Lu-PSMA radioligand therapy with major response, i.e. complete response by imaging and substantial reduction of PSA. 177Lu-PSMA radioligand therapy gave only mild adverse effects. In conclusion, patients with metastatic prostate cancer, 177Lu-PSMA-617 radioligand therapy had an attractive therapeutic profile which had to be adjusted according to the patient's need.
\end{abstract}

Ключевые слова: metastatic prostate cancer; prostate specific membrane antigen; Lu-177-PSMA

Disclosure: The study did not have sponsorship. The authors declare no conflict of interest.

Received: 14.02.2018. Accepted: 07.03.2018.

For correspondence: Kalevi J. A. Kairemo; tel.: +358-10-773 2000; e-mail: kalevi.kairemo@docrates.com

For citations: Kairemo K., Joensuu T. Lu-177-PSMA treatment for metastatic prostate cancer -case examples of miracle responses. Herald Urology. 2018;6(1):65-75. DOI:10.21886/2308-6424-2018-6-1-65-75

\section{Лечение метастатического рака простаты с помощью Лютеций-177-ПСМА - примеры случаев удивительных реакций}

\author{
К. Кайремо, Т. Йоэнсуу
}

Онкологическая клиника Дократес; Хельсинки, Финляндия

Простат специфический мембранный антиген (ПСМА) экспрессируется при неблагоприятном течении рака простаты. ПСМА является основой для новых методов диагностики и тераностики. Терапия радиолигандом 177Lu-ПСМА в основном используется у пациентов с распространённой формой рака простаты. Это сообщение описывает двух пациентов: первый - с обширным метастатическим поражением, выявленным на первом визите, второй - с множественными рецидивами. Оба пациента были пролечены радиолигандом 177Lu-ПCMA с существенным ответом, то есть полной реакцией, подтверждённой методами визуализации и значительным снижением уровня ПСА. Терапия радиолигандом 177Lu-ПСMA имеет умеренные побочные эффекты. Пациенты с метастатическим раком простаты, подвергнутые терапии радиолигандом 177Lu-ПCMA-617 имели благоприятный терапевтический профиль, который был скорректирован в соответствии с потребностями пациента.

Key words: метастатический рак предстательной железы; простатспецифический мембранный антиген; лютеций-177-ПСМА 
Раскрытие информации: Исследование не имело спонсорской поддержки. Авторы заявляют об отсутствии конфликта интересов.

Поступила в редакцию: 14.02.2018. Принята к публикации: 07.03.2018

Автор для связи: Кайремо Калеви; тел.: +358-10-773 2000; e-mail: kalevi.kairemo@docrates.com

Для цитирования: Кайремо К., Йоэнсуу Т. Лечение метастатического рака простаты с помощью Лютеций-177ПСМА - примеры случаев удивительных реакций. Вестник урологии. 2018;6(1):65-75. DOI:10.21886/2308-64242018-6-1-65-75

\section{Introduction}

$\mathrm{M}$ ost of the patients who have local prostate cancer will be cured totally without any serious side effects especially if high dose rate brachytherapy can be used [1]. However, the primarily metastatic prostate cancer has to be treated and controlled rest of the men's life. If not diagnosed and treated in early stage, the aggressive prostate cancer will disseminate usually to the bones and lymph nodes [2, 3, 4]. The most traditional treatment of metastatic prostate cancer is based on permanent castration. In recent years hormone therapy is enhanced more and more often by Docetaxel chemotherapy already before castration resistance emerges according to the results of CHARTEED and STAMPEDE trials $[2,3]$. Our own experience supports to give also localized radiotherapy to the prostate, despite metastases, and to oligometastases using VMAT technique with radical doses $[1,4,5]$. In selected cases the HDR brachytherapy can be used as a boost to the prostate. If the cancer has been widely spread in to the bones, then our practice has been to complete the treatment with Radium-223 [4, 6, 7, 8].

Although the response can be complete for primary treatment, different maintenance medications will lose the efficacy soon or later. Prostate cancer can progress in bones and lymph nodes but sometimes it disseminates also to the liver or to the lungs. One of the most sensitive tumor markers in order to localize the spreading of the disease most precisely is 68Ga-PSMA-11 or more recently 18F-PSMA-1007-PET-CT. If tumor cells appears to be positive for PSMA in PET-CT scanning, that positivity can be used for treatment, where intravenously administered PSMA-labelled Lu-177 ( ${ }^{177}$ Lutetium-PSMA) radiopharmaceutical targets and destroys PSMA-positive metastases. The idea is to bring the radiation source in to the immediate vicinity of or even to the cancer cell in largely disseminated prostate cancer. Lutetium-177 is a $\beta$-emitter with the average beta particle range of about $1 \mathrm{~mm}$. The radiopharmaceutical is eliminated

\section{Введение}

Б ольшинство пациентов, у которых диагностируют локализованный рак простаты, могут быть пролечены полностью без какихлибо серьёзных побочных эффектов, в особенности если применяется брахитерапия в высокой дозе [1]. Однако первоначально метастатический рак простаты подлежит лечению и контролю в течение всей оставшейся жизни мужчины. При отсутствии лечения агрессивная форма рака простаты обычно диссеминирует в кости и лимфатические узлы $[2,3,4]$. Традиционные методы лечения метастатического рака простаты основаны на непрерывной гормональной терапии. В последние годы гормональная терапия все чаще усиливается химиотерапией доцетакселем ещё до того, как развивается резистентность к гормонотерапии в соответствии с результатами исследований CHARTEED и STAMPEDE $[2,3]$. Наш собственный опыт также поддерживает локальную лучевую терапию, несмотря на метастазы и олигометастазы, с использованием методики объемномодулированной лучевой терапии (VMAT) радикальными дозами $[1,4,5]$. В отдельных случаях брахитерапия с высокой мощностью дозы (HDR-брахитерапия) может быть использована в качестве поддерживающего лечения при раке простаты. Если рак широко распространён в костях, тогда данная практика должна завершаться лечением с помощью Радия-223 [4, 6, 7, 8].

Несмотря на то, что ответ может быть полным при первичном лечении, различные поддерживающие медикаменты рано или поздно утрачивают свою эффективность. Рак простаты может метастазировать в кости и лимфатические узлы, иногда в печень и лёгкие. Для наиболее точного определения распространения заболевания используют ${ }^{68} \mathrm{Ga}-$

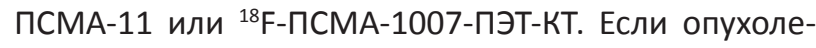
вые клетки при ПЭТ-КТ сканировании оказываются ПСМА-положительными, то этот эффект может быть использован для лечения рака путём внутривенного ведения ПСМА-лигандов, маркированных радиоактивным нуклидом Лютеций-177 ( ${ }^{177}$ Лютеций-ПСМА), разрушающих ПСМА-положительные метастазы. Идея состоит в том, чтобы при распространённом опухолевом процессе донести источник радиации как можно ближе или даже непосредственно в рако- 
from the body quickly, the effective half-life is about 2 days (the physical half-life is about 7 days). The treatment may be limited by the uptake of this radiopharmaceutical into salivary glands, which can cause dryness of the mouth, but according to our experience, possible side effects of the ${ }^{177}$ Lu-PSMA treatment are very minor.

${ }^{177}$ Lu-PSMA treatment is still considered experimental, eventhough excellent results have been reported. The German multicenter study reported already $40 \%$ of 145 patients responding after a single cycle of ${ }^{177}$ Lu-PSMA [9] and our own meta-analysis reported double-effect vs. the best new third-line treatments in metastatic prostate cancer $-50 \%$ PSA-decrease $44 \%$ vs. $22 \%$ in more than 650 patients treated with ${ }^{177}$ Lu-PSMA [10].

Here we report two patients with very different case histories who got complete response by imaging.

\section{Case reports}

Patient 1. Our first patient had primarily nocturia, pollacisuria and weak urinary flow resulting in more specific clinical studies. Initial S-PSA was $216 \mathrm{ng} /$ $\mathrm{ml}$. In 2014 biopsies were taken and histopathology revealed in all of them Gleason Score (GS) $9(5+4)$ adenocarcinoma with perineural invasion and extracapsular growth. Clinically the patient was $\mathrm{T4}$, but there were no skeletal metastases in bone scintigraphy. Total androgen blockade ( $T A B)$ with leuprorelin plus bicalutamide was started for locally advanced prostate cancer with bilateral hydronephrosis and serum creatinine value 150 . Nephrostomies were made by placing bilateral pyelostomies on both sides. After operations, the patient could also urinate normally twice a day. Pyelostomies were changed to JJ-stents inside both ureters. The right ureter stent was changed to a new one later on. New changes of stents on both sides were again performed. TAB continued until March 2017. Bone scintigraphy already in February 2017 demostrated a superscan, and in early March CT showed bone metastases with serum PSA value 135 $\mathrm{ng} / \mathrm{ml}$, without visceral metastases. At the end of March bicalutamide was stopped and abiraterone was started. Abiraterone was again stopped when ${ }^{177}$ Lutetium-PSMA started. Patient refused to take any chemotherapy.

Ga-68-PSMA-PET/CT was performed at Docrates Cancer Center in late April 2017. It revealed an active and aggressive prostate malignancy in the left seminal vesicle region and extensive widespread strongly PSMA-positive skeletal disease. The Soloway classification was $3+/ 3$, because extremely вую клетку. Лютеций-177 это $\beta$-эмиттер со средним диапазоном для бета-частиц приблизительно 1 мм. Радиофармацевтический агент быстро элиминируется из организма, эффективное время полужизни составляет примерно 2 дня (физическое время полужизни составляет примерно 7 дней). Лечение может быть ограничено путём захвата этого радиофармацевтического агента слюнными железами, что может вызывать сухость полости рта, но в соответствии с нашим опытом данные побочные эффекты лечения ${ }^{177} \mathrm{Lu}-$ ПCMA встречаются редко.

Лечение с помощью ${ }^{177} \mathrm{Lu}$ - ПCMA по-прежнему считается экспериментальным, хотя имеются хорошие результаты. Немецкое мультицентровое исследование сообщило, что из 115 пациентов после однократного цикла терапии ${ }^{177}$ Lu-ПCMA положительный ответ наблюдался в $40 \%$ случаев [9] Наш метаанализ показал -двойной эффект в сравнении с методами третьей линии терапии при метастатическом раке простаты $-50 \%$ снижение уровня ПСА в $44 \%$ против 22 \% более чем у 650 пациентов, получавших ${ }^{177}$ Lu-ПCMA [10].

В этой статье мы сообщаем о двух пациентах с различным анамнезом, которые имели полный ответ на терапию ${ }^{177} \mathrm{Lu}-П \mathrm{CMA}$, доказанный методами визуализации.

\section{Клинические случаи}

Пациент 1. Первый пациент изначально имел ноктурию, поллакиурию и слабую струю мочи, что потребовало определённого клинического обследования. Первоначальный уровень ПСА составлял 216 нг/мл. В 2014 г. были взяты биоптаты простаты и отправлены на гистопатологическое исследование, которое показало во всех образцах аденокарциному с суммой по Глисону $9(5+4)$, периневральной инвазией и экстракапсулярным ростом. Клинически пациент находился на четвертой стадии Т4, но по данным сцинтиграфии костей метастазов не выявлено. По поводу местно-распространённого рака простаты с двухсторонним гидронефрозом была начата общая андрогенная блокада лейпрорелином и бикалутамидом. Уровень креатинина составлял 150 мкмоль/л. Нефростомии были выполнены билатерально. После операции пациент также мог нормально мочиться два раза в день. Пиелостомы были заменены на JЈ-стенты ретроградно в обеих мочеточниках. Спустя некоторое время стент правого мочеточника был заменен на новый. В последующем произведены двусторонние замены стентов. Общая андрогенная блокада продолжалась до марта 2017 г. Сцинтиграфия костей уже в феврале 2017 г. показала наличие метастазов. В начале марта костные метастазы были диагностированы при КТ, данных за наличие висцеральных метастазов не было. Уровень ПСА составлял 135 нг/мл. В конце марта бика- 
high uptakes in lower thoracic spine and sacrum and signs of bone marrow expansion existed. The SUVmax-values were higher than 27 , while values higher than 3 are considered pathologic. The serum PSA value was $375 \mathrm{ng} / \mathrm{ml}$.

${ }^{177}$ Lu-PSMA therapy started in mid-May 2017. It caused tiredness and he had also swelling in foots and ankles, but surgical stockings helped that. The patient had also severe depression and anguish. Following 4th treatment in September 2017 man had nausea and emesis. Figures1 demonstrate the blood parameters during the 4 first cycles of ${ }^{177}$ Lu-PSMA therapies illustrating that these treatments were not hematotoxic. There were no signs of renal or liver toxicity either. After 6th treatment he had no nausea and general feeling was also good. This man is now 70 years old.

An interim control Ga-68-PSMA-11-PET/CT was performed at Docrates Cancer Center in late October 2017. The serum value was $9.4 \mathrm{ng} / \mathrm{ml}$. Figure 2 demonstrates the Ga-68-PSMA-11-PET/ CT-studies performed in late April and late October 2017, i.e. before therapies and 4 weeks after the 4th cycle. In the base line study an extensive skeletal disease can be seen in the MIP-image and also in pelvic fusion image (PET on CT). Normal organs, i.e. salivary and lacrimal glands, liver, spleen hardly visualize in the MIP-image. Additionally, an uptake is seen in the large prostate and in the left seminal vesicle. The interim control PET MIP-image reveals normal organs such as salivary and lacrimal glands, liver, spleen, kidneys and urinary bladder. Very little activity can be observed in the thoracic vertebra (Th 3). In interim control pelvic fusion image (PET on CT) there is no activity in the large prostate nor in the left seminal vesicle.

In control Ga-68-PSMA-PET/CT on in mid-January 2018 at Docrates Cancer Center and 6 weeks after the 6th cycle the active and aggressive prostate malignancy in the left seminal vesicle region had totally disappeared. Similarly, an extensive widespread strongly PSMA-positive skeletal disease, original classification probably $3+/ 3$, had responded in all regions. There was only one subtle uptake on the left in Th3 which could be seen as in Fig.2, but the activity could already be considered normal, because the SUVmax value was only 3.8. This was considered as a dramatic response. PSA decreased from $375 \mathrm{ng} / \mathrm{ml}$ down to $4.2 \mathrm{ng} / \mathrm{ml}$ during the follow-up 177Lu-PSMA therapy. This is shown in Figure 3.

Early February 2018 radical radiotherapy was started to the prostate, pelvic lymph nodes and seminal vesicles. During this radiotherapy course the remaining lesion in Th3 will be irradiated as well (3x9 Gy). лутамид был прекращён и начат абиратерон. Затем абиратерон вновь был прекращён и начато лечение ${ }^{177}$ Lu-ПCMA. Пациент отказался от какой-либо химиотерапии.

Ga-68-ПСМА-ПЭТ/КT, выполненная в онкологической клинике Дократес в конце апреля 2017 г., показала активную и агрессивную злокачественную опухоль простаты в области левого семенного пузырька и обширное ПСМА-положительное поражение костей. По классификации Soloway составляло 3+/3 изза чрезвычайно высокого захвата в нижнем грудном отделе позвоночника и в крестце, также отмечались признаки экспансии в костный мозг. Максимальные значения стандартизированного уровня накопления радиофармпрепарата ФДГ (SUVmax) были выше 27, в то время как значения более 3 рассматривались как патологические. Значение уровня ПСА в плазме крови составляло 375 нг/мл.

Терапия ${ }^{177}$ Lu-ПCMA, начатая в середине мая 2017 г., вызывала усталость, пациент отмечал отёчность ног и лодыжек, но хирургические компрессионные чулки препятствовали этому. Отмечалась тяжёлая депрессия и чувство тоски. При последующих четырёх циклах лечения мужчина отмечал тошноту и рвоту. На рисунке 1 представлены параметры крови во время четырёх первых циклов терапии ${ }^{177} \mathrm{Lu}-$ ПСМА. Они иллюстрируют, что эти методы лечения не были гематотоксичными. Не было каких-либо признаков токсического воздействия на печень и почки. На шестом цикле лечения тошнота отсутствовала, общее самочувствие было хорошим. Этому мужчине в настоящее время 70 лет.

Промежуточный контроль Ga-68-ПСМА-11-ПЭТ/ КТ был выполнен в онкологической клинике Дократес в конце октября 2017 г. Значение ПСА составляло 9,4 нг/мл. Рисунок 2 показывает Ga-68-ПСMA-11ПЭТ/КТ исследования, выполненные в конце апреля и в конце октября 2017 г., то есть до терапии и через 4 недели после четырёх циклов терапии. В исходном исследовании на изображениях, полученных методом проекции максимальной интенсивности, а также путём слияния изображений таза можно увидеть обширное поражение костей. Нормальные органы (слюнные и слёзные железы, печень, селезёнку) трудно визуализировать с помощью метода проекции максимальной интенсивности. Кроме того, захват наблюдался в увеличенной простате и в области левого семенного пузырька. Промежуточный контроль ПЭТ изображений, полученных методом проекции максимальной интенсивности показал нормальные органы, такие как слюнные и слёзные железы, печень, селезёнку, почки и мочевой пузырь. Очень малая активность наблюдается в третьем грудном позвонке (Th 3). При промежуточном контроле слияния изображений таза (ПЭТ на КТ) не отмечается активности ни в увеличенной простате, ни в левом семенном пузырьке. 


\section{Lab values during ${ }^{177}$ Lutetium-PSMA}

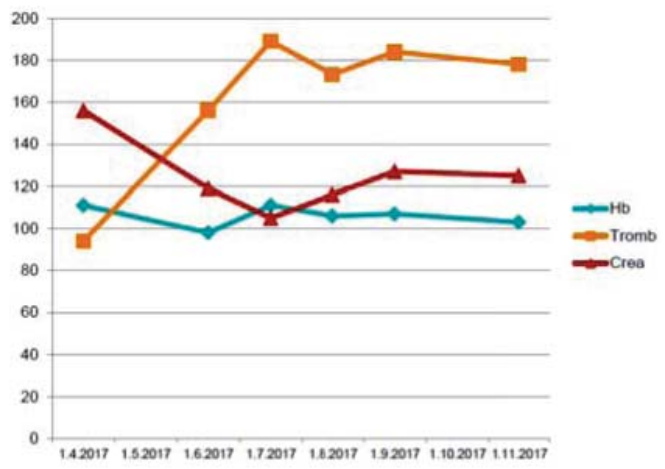

\section{Lab values during ${ }^{177}$ Lutetium-PSMA}

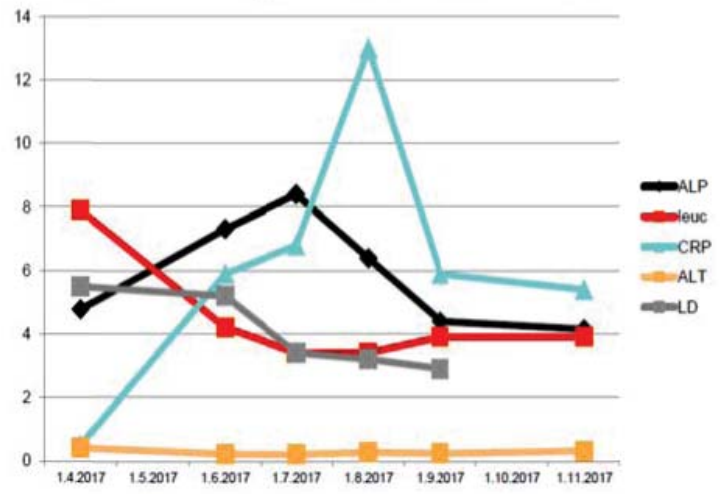

Figure 1. Hemoglobin, platelets and serum creatinine values during the four first cycles of 177Lu-PSMA-treament

(on the left). Alkaline phosphatase, leukocytes, CRP, alanine aminotransferase and lactate dehydrogenase values during the four first cycles of 177Lu-PSMA-treament (on the right).

Рисунок 1. Значения уровня гемоглобина, тромбоцитов и креатинина в течение первых четырех циклов лечения 177 Lu-ПCMA (слева). Значения уровней щелочной фосфатазы, лейкоцитов, С-реактивного белка, АЛТ и ЛДГ в течение первых четырёх циклов 177Lи-ПCMA (справа).

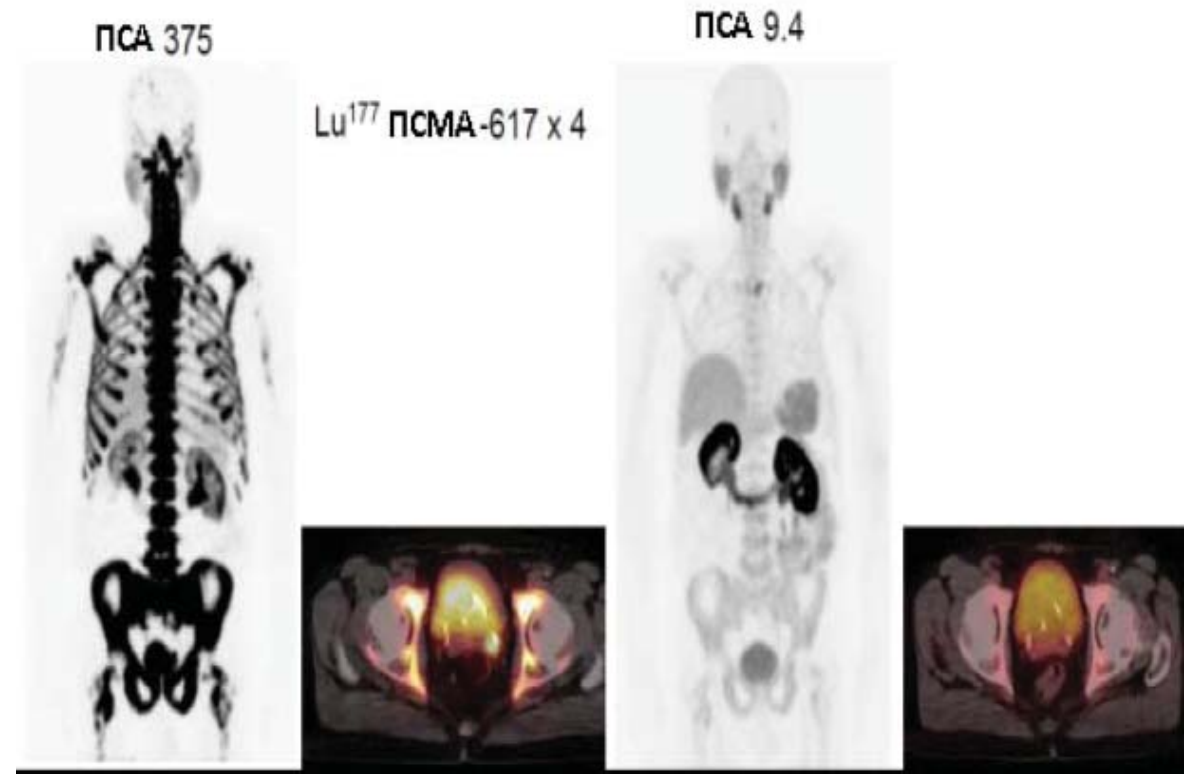

Figure 2. Two Ga-68-PSMA-PET/CT-studies performed in late April (on the left) and late October (on the right), i.e. before therapies and 4 weeks after the 4th cycle of 177Lu-PSMA-treaments.

In the April study an extensive skeletal disease can be seen in the MIP-image and also in pelvic fusion image (PET on CT) (left panel). Normal organs, i.e. salivary and lacrimal glands, liver, spleen hardly visualize in the MIP-image (left panel). There is also activity in the prostate and left seminal vesicle. In the October study the extensive skeletal disease

has fully disappeared in the MIP-image and soft-tissue disease also in pelvic fusion image (PET on CT) (right panel).

Normal organs, i.e. salivary and lacrimal glands, liver, spleen can be seen in the MIP-image (right panel).

Рисунок 2. Два исследования Ga-68-ПCMA-ПЭT/KT, выполненные в конце апреля (слева) и в конце октября 2017 г. (справа) то есть до терапии и через 4 недели после четырех циклов лечения 177Lи-ПCMA.

В исследовании, сделанном в апреле, можно увидеть обширное поражение костей на изображениях, полученных методом проекции максимальной интенсивности, а также на фьюжн-изображении (ПЭТ на

КT) (слева). Нормальные органы (слюнные и слёзные железы, печень, селезёнка) трудно визуализируются на изображениях, полученных методом проекции максимальной интенсивности (слева). Также отмечается активность в простате и в левом семенном пузырьке. В исследовании, сделанном в октябре, обширное

поражение костей полностью исчезло, по данным изображений, полученных методом проекции максимальной интенсивности), а также поражения мягких тканей путём слияния изображении тазовой области (fusion) (ПЭТ на КТ) (справа). Слюнные и слёзные железы, печень, селезёнку можно увидеть на изображениях, полученных методом проекции максимальной интенсивности. 

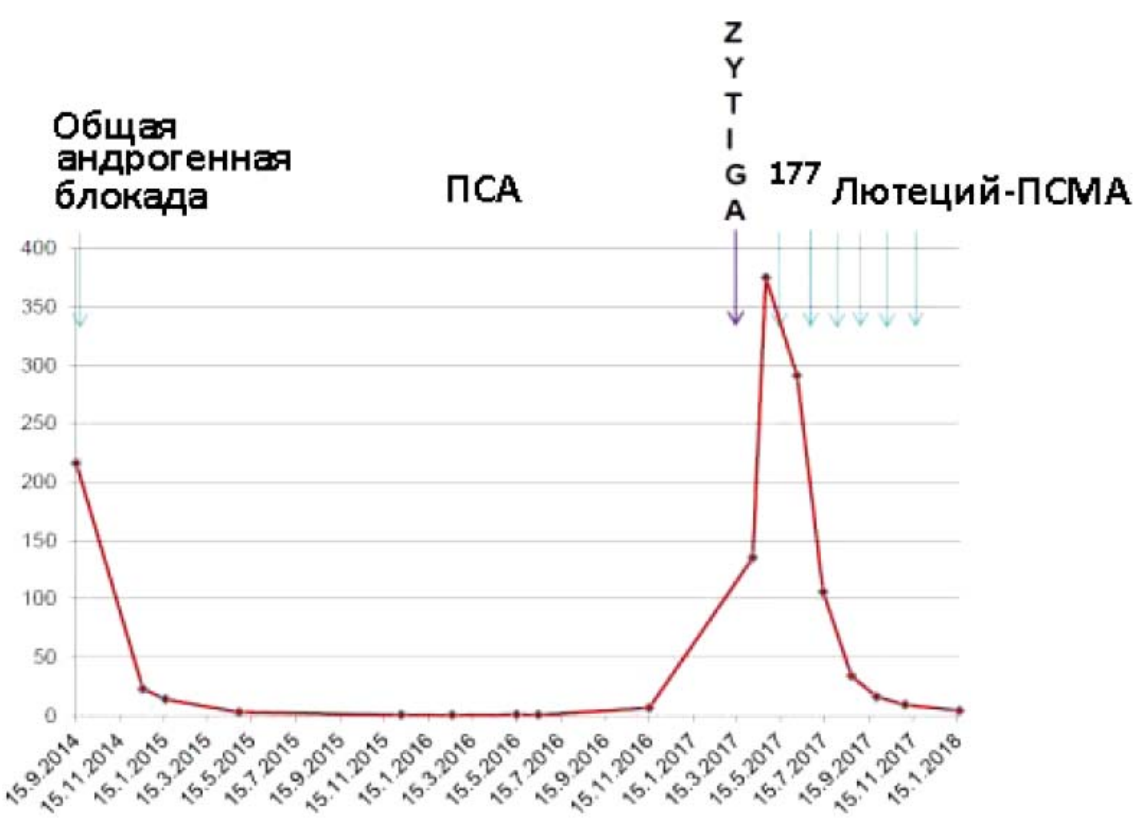

Figure 3. The serum PSA (ng/ml) curve of the patient who received six 177Lu-PSMA-treatments.

TAB means total androgen blockade (leuprorelin and bicalutamide). Abiraterone (Zytiga ${ }^{\circledR}$ ) was given after TAB, but stopped before177Lu-PSMA-treatments. The serum PSA decreased from 375 to $4.2 \mathrm{ng} / \mathrm{ml}$.

Рисунок 3. Кривая уровня ПСА (нг/мл) у пациента, который получил шесть циклов лечения 177Lu-ПCMA. Общая андрогенная блокада включала лейпрорелин и бикалутамид. Абиратерон (Zуtiga ${ }^{\circledR}$ ) был назначен после общей андрогенной блокады, но его приём был прекращён до лечения 177Lu-ПCMA. Уровни ПСА в плазме крови снизились от 375 нг/мл до 4,2 нг/мл.

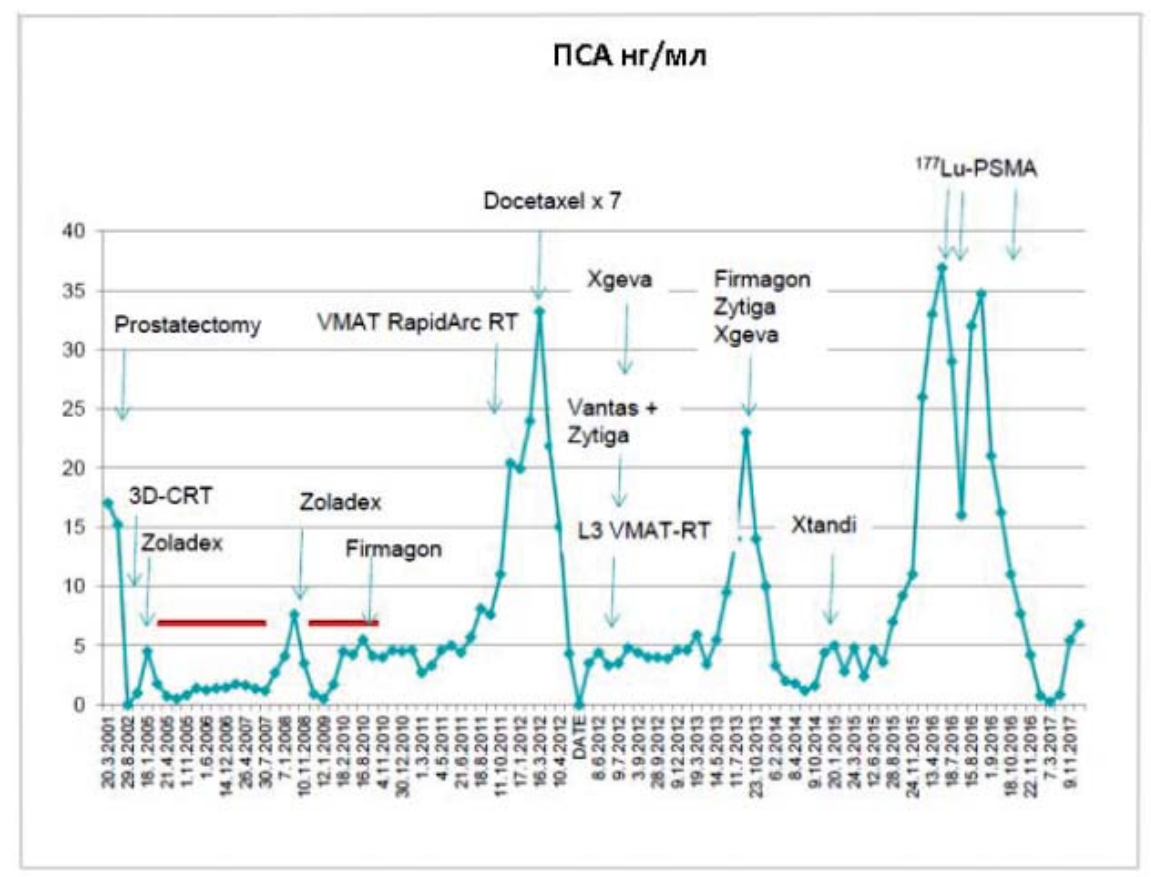

Figure 4. The serum PSA (ng/ml) curve of the patient who received three 177Lu-PSMA-treatments for his 5th relapse.

Рисунок 4. Кривая уровня ПСА (нг/Мл) у пациента, получавшего три цикла лечения 177LU-ПCMA по поводу его пятого рецидива. 
В начале февраля 2018 г. была начата лучевая терапия простаты, тазовых лимфатических узлов и семенных пузырьков. Во время курса лучевой терапии оставшаяся часть опухолевых поражений в области Th3 будет облучена в дозе 3х9 Гр.

Patient 2. Our second patient had hypertension and diabetes for years. He was operated due to duodenal ulcer and gallstones, and he had prosthesis in left elbow. Primarily PSA increased from 4.6 to $17 \mathrm{ng} / \mathrm{ml}$ within 6 months. Diagnosis was done based on second round of biopsies on in mid-April 2001 when GS $6(3+3)$ prostate adenocarcinoma was found in both lobes. In mid-May 2001 TAB was started with leuprorelin and bicalutamide. Prostatectomy was done in early-August 2001. Tumor was very large and it was infiltrating also to seminal vesicles, consistent with staging $\mathrm{pT} 3 \mathrm{~b}$, but it was not metastasized to locoregional lymph nodes. The full case history including serum PSA behavior is shown schematically in Figure 4, but briefly the case history is as follows.

In 2002 he got mamillar irradiation and radiation therapy to prostate fossa up to $70 \mathrm{~Gy}$. Bicalutamide was started early 2002 and stopped late 2004. Casodex started in March 2002 and stopped in October 2004. Goserelin started in January 2005 and paused in March 2007. Left kidney was small and had temporary hydronephrosis in July 2007. Bicalutamide was started in January 2008 again due to PSA increase (up to $4.1 \mathrm{ng} / \mathrm{ml}$ ). Degarelix was introduced from September 2010 to November 2011. Simultaneously in October 2011 cholinepositive para-iliac and paracaval lymph nodes were irradiated up to $70 / 2$ Gy. However, in February 2012 PSA was $24 \mathrm{ng} / \mathrm{ml}$ and 7 cycles of docetaxel were given with partial response. In June 2012 skeletal metastases were found in MRI: palliative radiotherapy to L3-sacrum region due to the pain was given 24/3 Gy in July 2012. Histrelin acetate device was implanted for castration. Abiraterone started in July 2012, denosumab in August, but they were stopped due to the pain in muscles and joints in November 2012. The castration implant removed and abiraterone started again in December 2012 and paused in March 2013. Denosumab started in January 2013 continuing until April 2014.

Degarelix which started in July 2013 was changed to leuprorelin in January 2015 due to local and systemic reaction. He also got radiation therapy to choline positive upper retroperitoneal and mediastinal lymph nodes. In January 2015 enzalutamide was started but it had to be stopped in February due to epileptic seizure. In June 2015 dexamethason combined with cyclophosphamide started to improve immunogenic response, but it
При контроле Ga-68-ПСМА-ПЭТ/КT в середине января 2018 г. в онкологической клинике Дократес и через 6 недель после шестого цикла активная и агрессивная злокачественная опухоль простаты в области левого семенного пузырька полностью исчезла. Аналогично обширное ПСМА-позитивное поражение костей, по оригинальной классификации возможно 3+/3 отвечало на терапию во всех областях. Только одна область захвата РФП отмечалось слева в Тh3 (рис. 2), но активность её уже могла считаться нормальной, потому что значения ФДГ (SUVmax) составляло только 3,8. Это расценивалось как впечатляющий ответ. Уровень ПСА снизился от 375 нг/мл до 4,2 нг/мл в течение периода наблюдения после терапии ${ }^{177} \mathrm{Lu}$-ПСMA1 (рис. 3).

Пациент 2. Второй пациент имел гипертензию и сахарный диабет. Он был прооперирован по поводу язвы двенадцатиперстной кишки и камней в желчном пузыре, имел протез левого коленного сустава. Первоначально в течение 6 месяцев уровень ПСА повышался от 4,6 до 17 нг/мл. Диагноз был установлен на основании результатов повторной биопсии, выполненной в середине апреля 2001 г., когда была обнаружена аденокарцинома простаты в обеих долях с суммой по Глисону 6 (3+3). В середине мая 2001 г. начата общая андрогенная блокада лейпрорелином и бикалутамидом. В начале августа 2001 г. выполнена простатэктомия. Опухоль имела большой объём, инфильтрировала семенные пузырьки, составляя стадию рТЗb, но не поражала местные региональные лимфатические узлы. Полный анамнез случая, включающий динамику уровня ПСА в плазме крови, показан схематически на рисунке 4.

В 2002 г. пациент получил курс лучевой терапии на область простаты в дозе до 70 Гр. Приём бикалутамида был начат в 2002 г. и прекращён в 2004 г. Касодекс - начат в марте 2002 г. и прекращён в октябре 2004 г. Гозерелин - начат в январе 2005 г. и приостановлен в марте 2007 г. Левая почка была уменьшена в размерах, в июле 2007 г. имел место временный гидронефроз. Приём бикалутамида вновь начат в январе 2008 г. вследствие повышения ПСА (до 4,1 нг/мл). Дегареликс вводили с сентября 2010 г. по ноябрь 2011 г. Одновременно в октябре 2011 г. позитивные подвздошные и паракавальные лимфатические узлы были облучены в дозе до 70/2 Гр. Однако в феврале 2012 г. уровень ПСА составлял 24 нг/мл, назначены 7 циклов доцетаксела с частичным ответом. В июне 2012 г. при МРТ обнаружены костные метастазы, вследствие наличия боли проведена паллиативная радиотерапия в области L3 в дозе 24/3 Гр. В июле 2012 г. подкожно установлен имплантат Хистрелин Ацетате (Vantas). Также в июле 2012 г. назначен абиратерон, а в августе деносумаб, но они были отменены в ноябре 2012 г. вследствие боли в мышцах и суставах. Кастрацион- 
had to be stopped due to the diarrhea, swelling and infection. Abiraterone started again in December 2015. In April 2016 PSA was 33 ng/ml. On the same day in Ga-68-PSMA-PET-CT at Docrates Cancer Center demonstrated active uptakes in very small lymph nodes on the left side of obturator region, in upper level in para-aortal and in para-caval lymph nodes and in retrocrural region, in the middle of left mediastinum and in supraclavicular region as well (Fig.5). The total volume of the disease estimated to be $20 \mathrm{~cm}^{3}$.

${ }^{177}$ Lu-PSMA-617 treatments were given in July, August and October 2016 using 6 week intervals. PSA nadir $0.0 \mathrm{ng} / \mathrm{ml}$ was achieved on in March 2017. Complete response was seen in 68Ga-PSMA-11 PETCT in March 2017 (Fig.5). The patient is still alive and followed without any specific cancer therapy until January 2018. However, he felt down and broke his femur which was operated. The man is now 82 years. ный имплант был удалён и вновь начат абиратерон в декабре 2012 г. и приостановлен в марте 2013 г. С января 2013 г. по апрель 2014 г возобновлён приём деносумаба.

Дегареликс, который был начат в июле 2013 г., был заменён на лейпрорелин в январе 2015 г. вследствие локальной и системной реакции. Пациент также получал лучевую терапию вследствие положительных верхних забрюшинных и медиастинальных лимфатических узлов. В январе 2015 г. начат приём энзалутамида и прекращён в феврале вследствие эпилептического приступа. В июне 2015 г. с целью улучшения иммунного ответа начат приём дексаметазона и циклофосфамида, но он был прекращён вследствие диареи, отёчности и инфекции. Абиратерон был вновь назначен в декабре 2015 г. В апреле 2016 г. уровень ПСА составлял 33 нг/мл. В тот же день Ga-68-ПСМA-ПЭТ-КT в онкологической клинике Дократес выявила активный захват в небольших лимфатических узлах с левой стороны в области

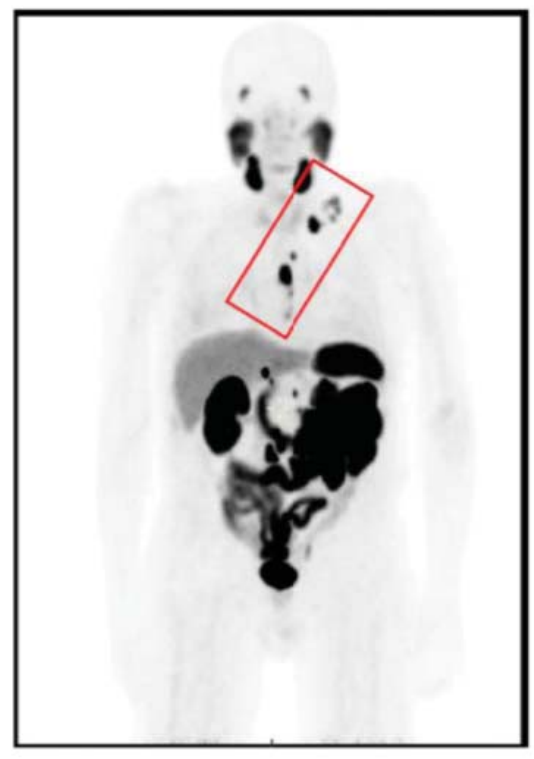

13.4.2016

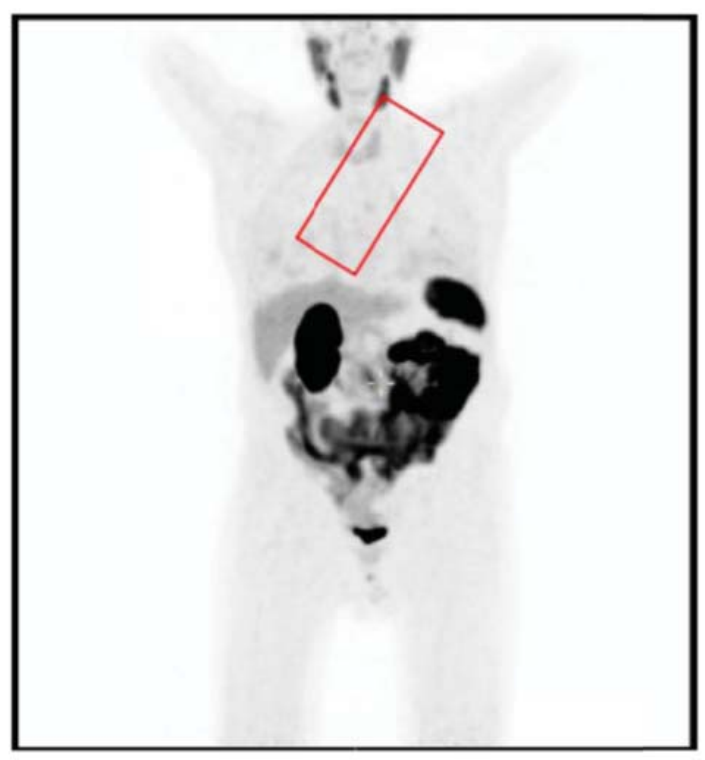

23.3.2017

Figure 5. Two Ga-68-PSMA-PET/CT-studies performed in April 2016 (on the left) and in March 2017 (on the right), i.e. before therapies and 5 months after the 3rd cycle of 177Lu-PSMA-treatments.

In the April 2016 study an extensive left side lymph node disease (obturatory, para-aortal retroperitoneal, retrocrural, left mediastinum and supraclavicular (red rectangle) can be seen in the MIP-image (left panel). Normal organs, i.e. salivary and lacrimal glands, liver, spleen visualize in the MIP-images (both panels). In the March 2017 study all the pathologic lymph nodes disappeared including the left mediastinum and supraclavicular regions (red rectangle) (right panel).

Рисунок 5. Два исследования Ga-68-ПСМА-ПЭт/КT были выполнены в апреле 2016 г. (слева) и в марте 2017 г. (справа,) то есть до терапии и через 5 месяцев после трёх циклов лечения 177Lu-ПCMA.

В исследовании в апреле 2016 г. было выявлено обширное поражение лимфатических узлов слевой стороны (запирательных, забрюшинных, парааортальных, ретрокруральных, левых медиастинальных и надключичных) (красный треугольник) можно увидеть с помощью метода проекции максимальной интенсивности (левая панель). Нормальные органы, то есть слюнные и слёзные железы, печень, селезёнка, визуализировались на изображениях, полученных с помощью метода проекции максимальной интенсивности (обе панели). В марте 2017 г. в исследовании все патологические лимфатические узлы исчезли, включая левое средостение и надключичные области (красный треугольник) (правая панель). 


\section{Discussion}

Here we report the Lu-177-PSMA treatment results in two patients, the first patient had extensive skeletal metastastic disease and this was first relapse during a 2-year follow-up time, and the second patient had his fifth relapse during a 15-year follow-up time. Both patients demonstrated major response, i.e. complete response by imaging and substantial reduction of serum PSA, i.e more than $95 \%$ reduction without any serious (grade $3-4$ ) side effects.

Therefore we recommend Lu-177-PSMA treatment for metastatic prostate cancer, especially when disease is wide-spread but the foci are still small in size. The treatment cycles are administered with 4-6 week intervals. Treatment response evaluated with laboratory tests, whole body Lu-177-PSMA-617 SPECT/CT imagings with and Ga-68-PSMA-11-PET/ $\mathrm{CT}$ imaging controls. Whole body SPECT/CT is also used for dose calculations. The treatment courses are individual: the interval, number of cycles and administered activity may vary as shown also in these patients.

The treatment is given as an intravenous infusion on the outpatient basis and it takes approximately 30 minutes to deliver. We monitor the Lu-177biodistribution by multiple imaging studies and external dose rate measurements.

\section{Conclusions}

We conclude that Lu-177 gives possibility for additional therapy especially for elderly prostate cancer patients, whose cancer progress and when chemotherapy is no more an option due to the poor tolerability and probable serious side effects. запирательной ямки, в паракавальных и парааортальных лимфатических узлах и ретрокруральной области, в середине левого средостения, а также в надключичной области (рис. 5). Общий объём поражения оценивался в $20 \mathrm{~cm}^{3}$.

Лечение ${ }^{177}$ Lu-ПCMA-617 проведено в июле, августе и октябре 2016 г. с 6-тинедельными интервалами. Надир значения ПСА 0,0 нг/мл был достигнут в марте 2017 г. Полный ответ наблюдался в марте 2017 г. на ${ }^{68} \mathrm{Ga}$-ПСМА-11 ПЭТ-КТ (рис. 5). Этот пациент до сих пор жив и наблюдается без какой-либо специфической терапии рака до января 2018 г. Однако он чувствует себя подавленным и сломал своё бедро, которое было прооперировано. В настоящее время мужчине 82 года.

\section{Обсуждение}

Представлены результаты лечения Lu-177-ПCMA двух пациентов, первый пациент имел обширные метастазы в костях и это был первый рецидив в течение 2 лет наблюдения, а второй пациент имел пятый рецидив в течение 15 лет наблюдения. Оба пациенты показали полную ответную реакцию, которая была подтверждена методами визуализации и значительным снижением уровня ПСА в плазме крови, то есть более, чем 95 \% снижение без каких-либо серьёзных (степень дифференцировки - 3-4) побочных эффектов.

Лечение Lu-177-ПCMA рекомендовано при метастатическом раке простаты, особенно, когда заболевание является обширным, но фокусы до сих пор являются небольшими по размеру. Циклы лечения проводятся с интервалом 4-6 недель. Ответ на лечение оценивается с помощью лабораторных тестов, визуализации всего организма человека с использованием Lu-177-ПСMA-617 SPECT/KT и Ga-68-ПCMA11-ПЭТ/КТ в качестве контроля. Методика SPECT/КT также используется для расчёта дозы. Эти курсы лечения являются индивидуальными: интервал, число циклов и назначаемая активность могут варьироваться, как было показано у этих пациентов.

Это лечение назначается в виде внутривенной инфузии на амбулаторной основе и занимает приблизительно 30 минут. Мы мониторируем биологическое распределение Lu-177 с помощью многих методов визуализации, а также при помощи измерений показателя внешней дозы.

\section{Выводы}

Lu-177 даёт возможность дополнительной терапии, особенно для пожилых пациентов с раком простаты, у которых он прогрессирует, когда химиотерапия больше не является опцией для лечения вследствие плохой переносимости и возможных серьёзных побочных эффектов. 


\section{REFERENCES}

1. Kiljunen $T$, Kangasmäki A, Aaltonen A, Kairemo K, Partanen K, Joensuu G, Alanko T, Vaalavirta L, Joensuu T. VMAT technique enables concomitant radiotherapy of prostate cancer and pelvic bone metastases. Acta Oncol. 2015;54(6):847-53. doi:10.3109/0284186X.2014.962665

2. Sweeney CJ, Chen YH, Carducci M, Liu G, Jarrard DF, Eisenberger M, Wong YN, Hahn N, Kohli M, Cooney MM, Dreicer R, Vogelzang NJ, et al. Chemohormonal therapy in metastatic hormone sensitive prostate cancer. N Engl J Med. 2015;373:737-746. doi: 10.1056/NEJMoa1503747

3. James ND, Sydes MR, Clarke NW, Mason MD, Dearnaley DP, Spears MR, Ritchie AW, Parker CC, Russell JM, Attard G, de Bono J, Cross W, Jones RJ, Thalmann G, Amos C, Matheson D, Millman R, Alzouebi M, Beesley S, Birtle AJ, Brock S, Cathomas R, Chakraborti P, Chowdhury S, Cook A, Elliott T, Gale J, Gibbs S, Graham JD, Hetherington J, Hughes R, Laing R, McKinna F, McLaren DB, O'Sullivan JM, Parikh O, Peedell C, Protheroe A, Robinson AJ, Srihari N, Srinivasan R, Staffurth J, Sundar S, Tolan S, Tsang D, Wagstaff J, Parmar MK; STAMPEDE investigators. Addition of docetaxel, zoledronic acid, or both to first-line long-term hormone therapy in prostate cancer (STAMPEDE): Survival results from an adaptive, multiarm, multistage, platform randomised controlled trial. Lancet. 2016;387(10024):1163-77. doi: 10.1016/ S0140-6736(15)01037-5

4. Joensuu $T$, Joensuu $G$, Kairemo $K$, Kiljunen $T$, Riener $M$, Aaltonen A, Ala-Opas $M$, Kangasmäki A, Alanko T, Taipale L, Hervonen P, Bützow A, Virgolini I, Hemminki A. Multimodal Primary Treatment of Metastatic Prostate Cancer with Androgen Deprivation and Radiation. Anticancer Res. 2016;36(12):6439-6447. doi: 10.21873/ anticanres.11242

5. Kairemo K, Rasulova N, Kiljunen T, Partanen K, Kangasmäki A, Joensuu T. PET/CT Dose Planning for Volumetric Modulated Arc Radiation Therapy (VMAT) -Comparison with Conventional Approach in Advanced Prostate Cancer Patients. Curr Radiopharm. 2015;8(1):2-8.

6. Parker C, Nilsson S, Heinrich D, Helle SI, O'Sullivan JM, Fosså SD, Chodacki A, Wiechno P, Logue J, Seke M, Widmark A, Johannessen DC, Hoskin P, Bottomley D, James ND, Solberg A, Syndikus I, Kliment J, Wedel S, Boehmer S, Dall'Oglio M, Franzén L, Coleman R, Vogelzang NJ, O'Bryan-Tear CG, Staudacher K, Garcia-Vargas J, Shan $\mathrm{M}$, Bruland $\varnothing \mathrm{S}$, Sartor O; ALSYMPCA Investigators. Alpha emitter radium-223 and survival in metastatic prostate cancer. N Engl J Med. 2013;369(3):213-23. doi: 10.1056/ NEJMoa1213755

7. Poeppel TD, Handkiewicz-Junak D, Andreeff $M$, Becherer A, Bockisch A, Fricke E, Geworski L, Heinzel A, Krause BJ, Krause T, Mitterhauser M, Sonnenschein W, Bodei L, Delgado-Bolton RC, Gabriel M. EANM guideline for radionuclide therapy with radium-223 of metastatic castration-resistant prostate cancer. Eur J Nucl Med Mol Imaging. 2017. doi: 10.1007/s00259-017-3900-4

8. Kairemo K, Joensuu T. Radium-223-Dichloride in Castration Resistant Metastatic Prostate CancerPreliminary Results of the Response Evaluation Using F-18-Fluoride PET/CT. Diagnostics (Basel). 2015;5(4):41327. doi: $10.3390 /$ diagnostics5040413.

9. Rahbar K, Ahmadzadehfar H, Kratochwil C, Haberkorn U, Schäfers M, Essler M, Baum RP, Kulkarni HR, Schmidt M, Drzezga A, Bartenstein P, Pfestroff A, Luster M, Lützen U,

\section{ЛИТЕРАТУРА}

1. Kiljunen $T$, Kangasmäki A, Aaltonen A, Kairemo $K$, Partanen K, Joensuu G, Alanko T, Vaalavirta L, Joensuu T. VMAT technique enables concomitant radiotherapy of prostate cancer and pelvic bone metastases. Acta Oncol. 2015;54(6):847-53. doi:10.3109/0284186X.2014.962665

2. Sweeney CJ, Chen YH, Carducci M, Liu G, Jarrard DF, Eisenberger M, Wong YN, Hahn N, Kohli M, Cooney MM, Dreicer R, Vogelzang NJ, et al. Chemohormonal therapy in metastatic hormone sensitive prostate cancer. $N$ Engl J Med. 2015;373:737-746. doi: 10.1056/NEJMoa1503747

3. James ND, Sydes MR, Clarke NW, Mason MD, Dearnaley DP, Spears MR, Ritchie AW, Parker CC, Russell JM, Attard G, de Bono J, Cross W, Jones RJ, Thalmann G, Amos C, Matheson D, Millman R, Alzouebi M, Beesley S, Birtle AJ, Brock S, Cathomas R, Chakraborti P, Chowdhury S, Cook A, Elliott T, Gale J, Gibbs S, Graham JD, Hetherington J, Hughes R, Laing R, McKinna F, McLaren DB, O'Sullivan JM, Parikh O, Peedell C, Protheroe A, Robinson AJ, Srihari N, Srinivasan R, Staffurth J, Sundar S, Tolan S, Tsang D, Wagstaff J, Parmar MK; STAMPEDE investigators. Addition of docetaxel, zoledronic acid, or both to first-line long-term hormone therapy in prostate cancer (STAMPEDE): Survival results from an adaptive, multiarm, multistage, platform randomised controlled trial. Lancet. 2016;387(10024):1163-77. doi: 10.1016/S01406736(15)01037-5

4. Joensuu $T$, Joensuu $G$, Kairemo $K$, Kiljunen $T$, Riener M, Aaltonen A, Ala-Opas M, Kangasmäki A, Alanko T, Taipale L, Hervonen P, Bützow A, Virgolini I, Hemminki A. Multimodal Primary Treatment of Metastatic Prostate Cancer with Androgen Deprivation and Radiation. Anticancer Res. 2016;36(12):6439-6447. doi: 10.21873/anticanres.11242

5. Kairemo K, Rasulova N, Kiljunen T, Partanen K, Kangasmäki A, Joensuu T. PET/CT Dose Planning for Volumetric Modulated Arc Radiation Therapy (VMAT) Comparison with Conventional Approach in Advanced Prostate Cancer Patients. Curr Radiopharm. 2015;8(1):2-8.

6. Parker C, Nilsson S, Heinrich D, Helle SI, O'Sullivan JM, Fosså SD, Chodacki A, Wiechno P, Logue J, Seke M, Widmark A, Johannessen DC, Hoskin P, Bottomley D, James ND, Solberg A, Syndikus I, Kliment J, Wedel S, Boehmer S, Dall'Oglio M, Franzén L, Coleman R, Vogelzang NJ, O'Bryan-Tear CG, Staudacher K, Garcia-Vargas J, Shan $\mathrm{M}$, Bruland $\varnothing \mathrm{S}$, Sartor O; ALSYMPCA Investigators. Alpha emitter radium-223 and survival in metastatic prostate cancer. N Engl J Med. 2013;369(3):213-23. doi: 10.1056/ NEJMoa1213755

7. Poeppel TD, Handkiewicz-Junak D, Andreeff $M$, Becherer A, Bockisch A, Fricke E, Geworski L, Heinzel A, Krause BJ, Krause T, Mitterhauser M, Sonnenschein W, Bodei L, Delgado-Bolton RC, Gabriel M. EANM guideline for radionuclide therapy with radium-223 of metastatic castration-resistant prostate cancer. Eur J Nucl Med Mol Imaging. 2017. doi: 10.1007/s00259-017-3900-4

8. Kairemo K, Joensuu T. Radium-223-Dichloride in Castration Resistant Metastatic Prostate CancerPreliminary Results of the Response Evaluation Using F-18-Fluoride PET/CT. Diagnostics (Basel). 2015;5(4):41327. doi: $10.3390 /$ diagnostics5040413.

9. Rahbar K, Ahmadzadehfar H, Kratochwil C, Haberkorn U, Schäfers M, Essler M, Baum RP, Kulkarni HR, Schmidt M, Drzezga A, Bartenstein P, Pfestroff A, Luster M, Lützen U, 
Marx M, Prasad V, Brenner W, Heinzel A, Mottaghy FM, Ruf J, Meyer PT, Heuschkel M, Eveslage M, Bögemann M, Fendler WP, Krause BJ. German Multicenter Study Investigating ${ }^{177}$ Lu-PSMA-617 Radioligand Therapy in Advanced Prostate Cancer Patients. J Nucl Med. 2017;58(1):85-90. doi: 10.2967/jnumed.116.183194

10. von Eyben FE, Roviello G, Kiljunen T, Uprimny C, Virgolini I, Kairemo K, Joensuu T. Third-line treatment and ${ }_{177} \mathrm{Lu}$ PSMA radioligand therapy of metastatic castration-resistant prostate cancer: a systematic review. Eur J Nucl Med Mol Imaging. 2018;45(3):496-508. doi: 10.1007/s00259017-3895-x

\section{Information about the authors}

Kalevi J. A. Kairemo - Department of Molecular Radiotherapy and Nuclear Medicine, Docrates Cancer Center, Helsinki, Finland

ORCID iD 0000-0002-5194-746X

e-mail: kalevi.kairemo@docrates.com

Timo K. Joensuu - Department of Medical Oncology and Clinical Radiotherapy, Docrates Cancer Center, Helsinki, Finland

ORCID 0000-0002-0455-8031
Marx M, Prasad V, Brenner W, Heinzel A, Mottaghy FM, Ruf J, Meyer PT, Heuschkel M, Eveslage M, Bögemann M, Fendler WP, Krause BJ. German Multicenter Study Investigating ${ }^{177}$ Lu-PSMA-617 Radioligand Therapy in Advanced Prostate Cancer Patients. J Nucl Med. 2017;58(1):85-90. doi: 10.2967/jnumed.116.183194

10. von Eyben FE, Roviello G, Kiljunen T, Uprimny C, Virgolini I, Kairemo K, Joensuu T. Third-line treatment and ${ }_{177} \mathrm{Lu}-$ PSMA radioligand therapy of metastatic castrationresistant prostate cancer: a systematic review. Eur J Nucl Med Mol Imaging. 2018;45(3):496-508. doi: 10.1007/ s00259-017-3895-x

\section{Сведения об авторах}

Кайремо Калеви - отделение ядерной медицины и молекулярной радиотерапии,

Онкологическая клиника Дократес, Хельсинки, Финляндия

ORCID iD 0000-0002-5194-746X

e-mail: kalevi.kairemo@docrates.com

Йоэнсуу тимо - отделение медицинской онкологии и радиотерапии, Онкологическая клиника Дократес, Хельсинки, Финляндия

ORCID 0000-0002-0455-8031 